\title{
Modeling and Analysis of Homojunction Silicon Solar Cell
}

\author{
Ghada G. Younise \\ Department of Physics \\ College of Science \\ Mosul University
}

(Received 28/6/2010; Accepted 11/10/2010)

\begin{abstract}
The analysis of solar cell performance in terms of material and microscopic device parameters is the key to understanding device performance and efficiency. The purpose of this paper is to study and analysis the $(\mathrm{n}+\mathrm{p})$ homojunction silicon solar cell, and study for regions of solar cell which the base, depletion and emitter region after determent the parameters such a sample. And finding the quantum efficiency for this cell, and studying the effect of the recombination velocity of minority carriers and different diffusion lengths on the performance of the solar cell.
\end{abstract}

Keywords: Silicon solar cell; quantum efficiency; crystalline silicon.

\section{نمخجة وتحلال خليقشطسيقسايكونية أحالية الفرق}

\section{المانص}

تحللل أداء الخلية للثطسية بدلالة المتغيرات الماية والمايكروسكوبية هو المفتاح لفهم أداء النبطة

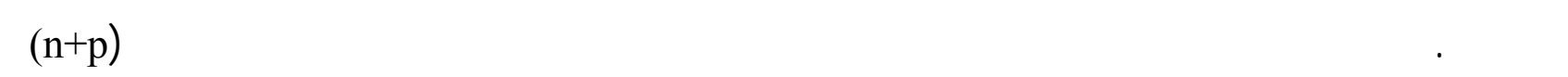
ودرلسة لجززاء الخلية وهي مظقة القاعة، الإستنزف والباعث بعد تحديد مواصفاتتها كنموذج. وإيجاد الكفاءة الكمية، ودرلسة تأثير سررعة إعاة اتحاد حلملات الأفلية وتأثير أطاول النشار مختلفة على أداء الخلية اللثمسية .

\section{INTRODUCTION}

Two principal sets of electric characteristics are used to consider cell performance: the $\mathrm{I}-\mathrm{V}$ curve and the spectral response (SR). The I-V curve gives the fundamental parameters of cell, i.e. short circuit current, open circuit voltage, fill factor and the cell efficiency. The SR or, equivalently, the quantum efficiency (QE) gives how the cell responds to the incoming photon fluxes in each device region. It also contains the richest information such as the effect of surface recombination velocities and the minority carrier diffusion length on 
the performance of the solar cells, which indicate the quality of the cell and the fabrication process. The quantum efficiency is presented as a function of wavelength (Gray, 2003).

When a solar cell is illuminated by sunlight, a photon with energy less than silicon solar cell band gap does not contribute to the photocurrent of solar cell. However, a photon with energy greater than solar cell band gap will create an electron-hole pair. The quantum efficiency is defined as the ratio of electron-hole pairs collected with respect to the number of incident photons which is (Khalvati, 2003):

- External quantum efficiency: number of carriers collected per incident photon at each wavelength.

- Internal quantum efficiency: number of carriers collected per Absorbed photon at each wavelength.

A study and analysis of quantum efficiency have been carried by (Salih, 2000; Castaner and Silvestre, 2002; Khalvati, 2003; Lipinski and Panek, 2003; Van Sark et al., 2004; McIntosh et al., 2009; Jahanshah et al., 2009). The aim of this study is to present analytical modeling and simulation results of $(n+p)$ homojunction solar cell and produce the quantum efficiency for different qualities of bulk, front and rear surface of the solar cell.

\section{THEORY}

A solar cell can be schematically described by the geometry shown in Fig. (1). The cell is formed by a very thin and heavily doped n-region is called the emitter, and a thick and less doped p-region is called the base. The illumination is through n-region window. The space charge region (SCR), with width (w) therefore extends mainly into p-region (which is less doped) and there is an electric field (E) inside SCR which depletes it from the free carriers. The point (xj) marks the penetration depth of the p-n junction and $\mathrm{H}$ is the crystal thickness. Ln and Lp are the diffusion length of electrons and holes respectively.

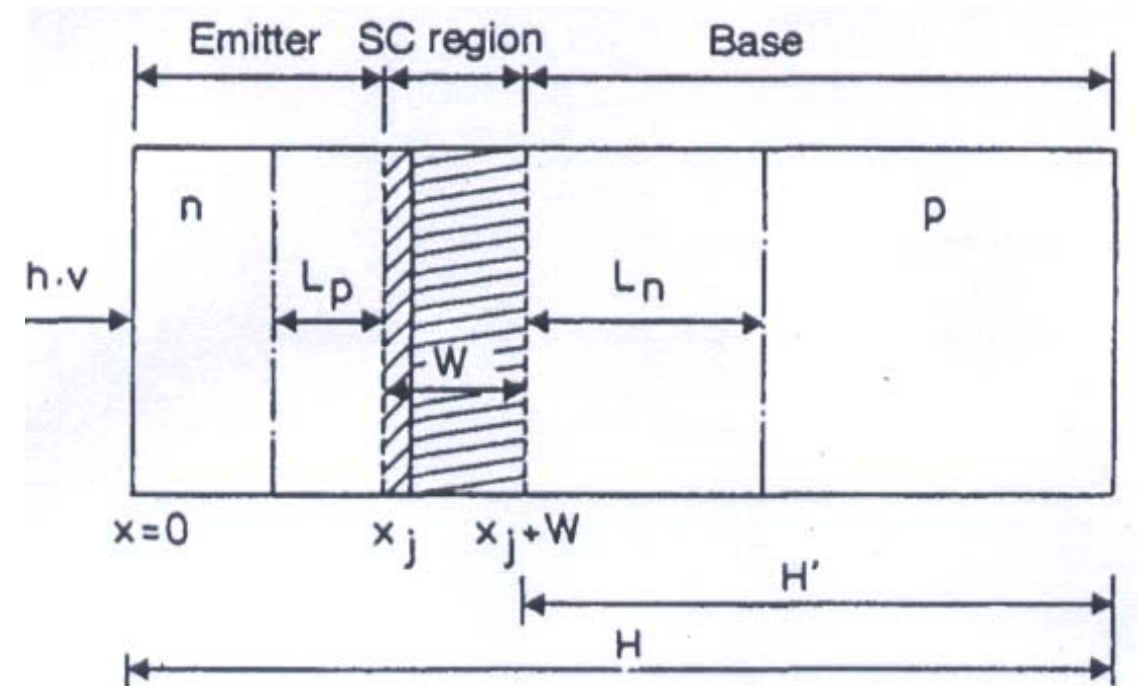

Fig. 1 : Structure of the $\mathrm{n}+\mathrm{p}$ homojunction silicon solar cell. 
By calculating the internal quantum efficiency for a range of wavelengths, one can obtain the total current generated by light (photocurrent) in the whole wavelengths range. Then the total photocurrent density obtained from the solar spectral distribution $F(\lambda)$, is given by (Sze and $\mathrm{Ng}, 2007$ ):

$$
\mathrm{J}_{\mathrm{ph}}=\mathrm{q} \int_{0}^{\lambda \mathrm{m}} \mathrm{F}(\lambda)[1-\mathrm{R}(\lambda)] \mathrm{QE} \text { sum }(\lambda) \mathrm{d} \lambda .
$$

Where $\lambda \mathrm{m}$ - is the longest wavelength corresponding to the semiconductor band gap.

$\mathrm{R}(\lambda)$ - is the reflection coefficient.

$\mathrm{QE}_{\text {sum }}(\lambda)$ - is the total quantum efficiency for the emitter, base and space charge regions.

$$
\mathrm{QE}_{\mathrm{sum}}(\lambda)=\frac{1}{q F(\lambda)[1-R(\lambda)]}\left[\mathrm{J}_{\mathrm{em}}(\lambda)+\mathrm{J}_{\mathrm{bas}}(\lambda)+\mathrm{J}_{\mathrm{SCR}}(\lambda)\right]
$$

Where $\mathrm{J}_{\mathrm{em}}(\lambda)$ - the photocurrent from the emitter is given by (Goetzberger et al., 1998) :

$$
\begin{gathered}
\mathrm{J}_{\mathrm{em}}(\lambda)=\frac{q F(\lambda)[1-R(\lambda)] \alpha L p}{\alpha^{2} L p^{2}-1} \times \\
{\left[\frac{\frac{\mathrm{SpLp}}{\mathrm{Dp}}+\alpha \mathrm{Lp}-\exp (-\alpha \mathrm{xj})\left[\left[\frac{\mathrm{SpLp}}{\mathrm{Dp}}\right] \cosh \left[\frac{\mathrm{xj}}{\mathrm{Lp}}\right]+\sinh \left[\frac{\mathrm{xj}}{\mathrm{Lp}}\right]\right]}{\left[\frac{\mathrm{SpLp}}{\mathrm{Dp}}\right] \sinh \left[\frac{\mathrm{xj}}{\mathrm{Lp}}\right]+\cosh \left[\frac{\mathrm{xj}}{\mathrm{Lp}}\right]}-\alpha \operatorname{Lp} \exp (-\alpha \mathrm{xj})\right]}
\end{gathered}
$$

$\mathrm{J}_{\mathrm{bas}}(\lambda)$ - the photocurrent from the base is given by (Goetzberger et al., 1998) :

$$
\begin{gathered}
J_{b a s}(\lambda)=\frac{q F(\lambda)[1-R(\lambda)] \alpha L n}{\alpha^{2} L n^{2}-1} \times \exp (-\alpha(x j+w)) \\
{\left[\alpha \operatorname{Ln}-\frac{\frac{S n L n}{D n}\left[\cosh \left[\frac{H^{\prime}}{L n}\right]-\exp \left(-\alpha H^{\prime}\right)\right]+\sinh \left[\frac{H^{\prime}}{L n}\right]+\alpha \operatorname{Ln} \exp \left(-\alpha H^{\prime}\right)}{\frac{S n L n}{D n} \sinh \left[\frac{H^{\prime}}{L n}\right]+\cosh \left[\frac{H^{\prime}}{L n}\right]}\right]}
\end{gathered}
$$

$\mathrm{J}_{\mathrm{SCR}}(\lambda)$ - the photocurrent from the space charge region is (Goetzberger et al., 1998) :

$$
\mathrm{J}_{\mathrm{SCR}}=\mathrm{q} F(\lambda)[1-\mathrm{R}(\lambda)] \exp (-\alpha \mathrm{xj})(1-\exp (-\alpha \mathrm{w}))
$$

In this equations :

$\alpha(\lambda)$ - is absorption coefficient (unit:1/cm) that depends on the wavelength.

$\mathrm{Sp}, \mathrm{Sn}$ - is the surface recombination velocity of holes and Electrons.

$\mathrm{Dp}, \mathrm{Dn}$ - is the hole and electron diffusion coefficient.

$\mathrm{H}^{\prime}$ - is the thickness of the base which is equal to :

$\mathrm{H}^{\prime}=\mathrm{H}-\mathrm{w}-\mathrm{xj}$ 


\section{Modeling of Solar Cell}

The modeling of solar cell has been made by Microsoft Excel computer program which is an electronic spreadsheet program. The cell parameters chosen for the simulation for the present model are summarized in Table (1). (Hovel, 1975).

Table 1: Main parameters involved in the analytical model.

\begin{tabular}{|l|c|c|}
\hline \multicolumn{1}{|c|}{ Parameter } & Value & Units \\
\hline Donor density Nd & $5^{*} 10^{19}$ & $\mathrm{~cm}^{-3}$ \\
\hline Hole diffusion coefficient in the emitter layer Dp & 1.295 & $\mathrm{~cm}^{2} / \mathrm{sec}$ \\
\hline Hole life time in the emitter layer $\tau_{\mathrm{p}}$ & $0.4^{*} 10^{-4}$ & $\mathrm{sec}$ \\
\hline Acceptor density Na & $1.5^{*} 10^{16}$ & $\mathrm{~cm}^{-3}$ \\
\hline Electron diffusion coefficient in the base layer Dn & 27 & $\mathrm{~cm}^{2} / \mathrm{sec}$ \\
\hline Electron diffusion length in the base layer Ln & 164 & $\mu \mathrm{m}$ \\
\hline Depletion width xj & 0.28 & $\mu \mathrm{m}$ \\
\hline Total cell thickness H & 450 & $\mu \mathrm{m}$ \\
\hline Junction depth xj & 0.5 & $\mu \mathrm{m}$ \\
\hline Surface recombination velocity for electrons Sn & 1000 & $\mathrm{~cm} / \mathrm{sec}$ \\
\hline Surface recombination velocity for holes Sp & 1000 & $\mathrm{~cm} / \mathrm{sec}$ \\
\hline
\end{tabular}

The absorption coefficient of crystalline silicon and the spectral distribution of the AM 1.5 solar spectrum used in our model calculation has been taken from ( Castaner and Silvester, 2002).

\section{RESULTS AND DISCUSSION}

The internal quantum efficiency of $(n+p)$ homojunction solar cell was studied. Figure (2) shows the total internal quantum efficiency is divided into three components, the base, emitter, and the depletion region contributions.

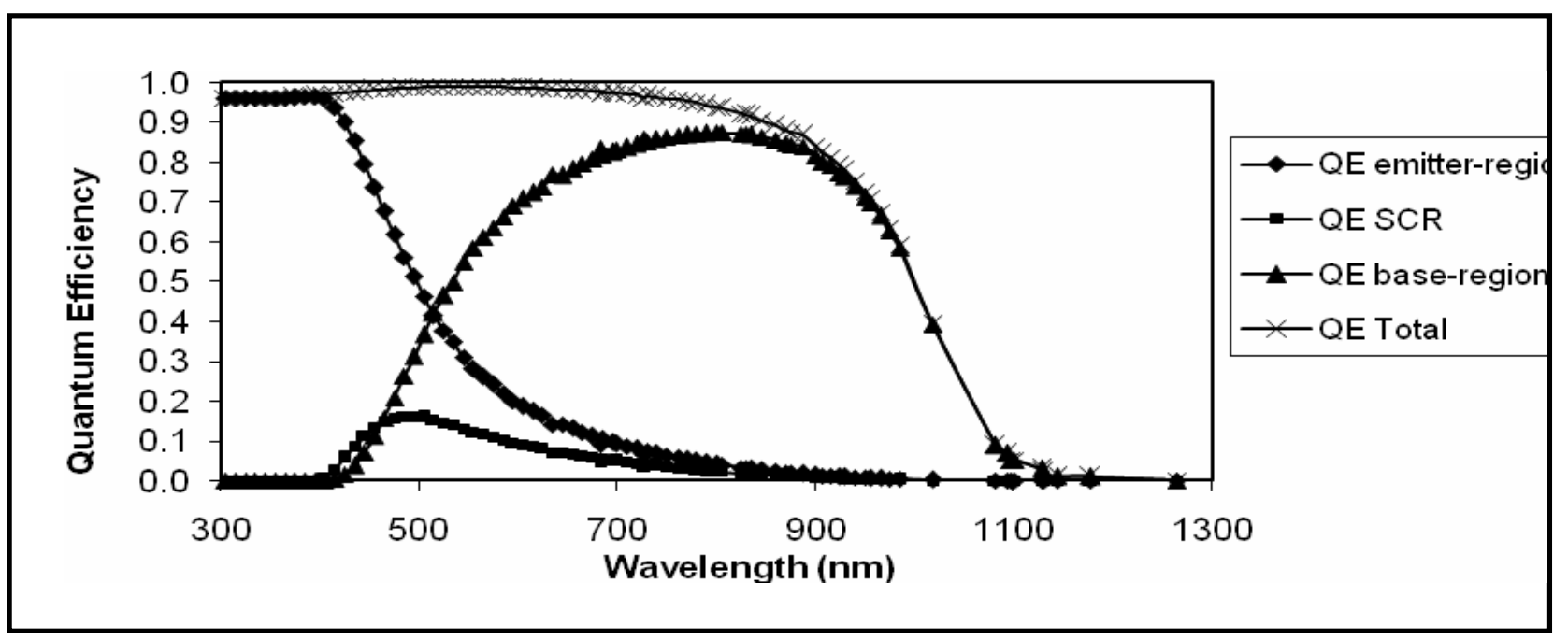

Fig. 2: $\mathrm{n}+\mathrm{p}$ solar cell internal quantum efficiency for emitter, base and space charge regions. 
At long photon wavelengths (i.e. low photon energies), most of the carriers are generated in the base due to the absorption of lower photon energies at the base, but as the photon wavelength decrease, the quantum efficiency for the emitter and depletion regions will increase, but the contribution from the depletion region is never becomes as large the emitter region component under any practical conditions because of the very high value of absorption coefficient above $3.2 \mathrm{eV}$ (i.e. $\lambda=387.5 \mathrm{~nm}$ ), which causes almost all the light at high energies to be absorbed in the region up to $1000 \mathrm{~A}^{\circ}$ (Hovel, 1975). The influence of the front and back surface recombination velocities on the cell efficiency depends on the diffusion lengths of the carriers. When the diffusion length of the electrons in p-region (Ln) is comparable to the width of the base (p-region) as shown in Figure (3), than the back surface velocity $(\mathrm{Sn})$ will play a major role in the quantum efficiency of cell. The reason is, the excess minority carriers will reach the back surface of the device before any recombination.

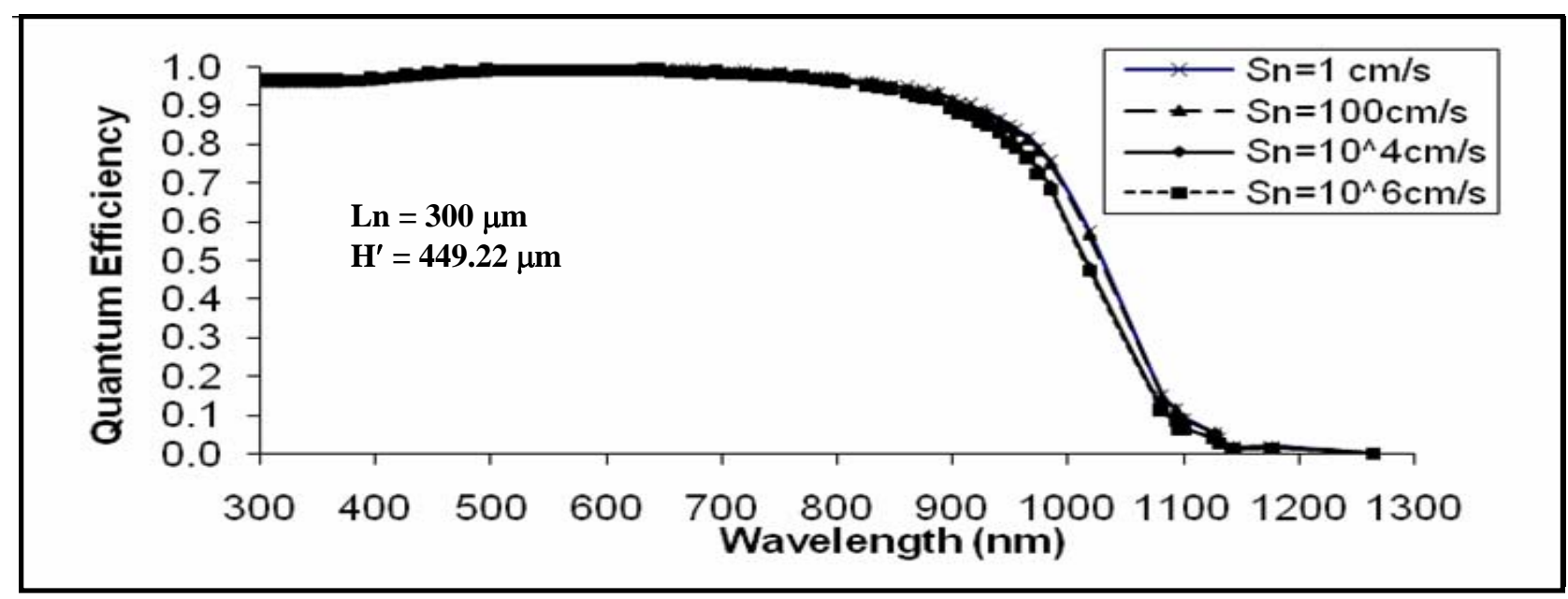

Fig. 3: $\mathrm{n}+\mathrm{p}$ solar cell internal quantum efficiency for different surface recombination velocities of electrons ( for long Ln).

In Figure (4) the diffusion length of electrons is much shorter than the base width, this means that the electrons will recombine before they reach the back surface, therefore, the back surface recombination velocity cannot affect in the quantum efficiency of cell.

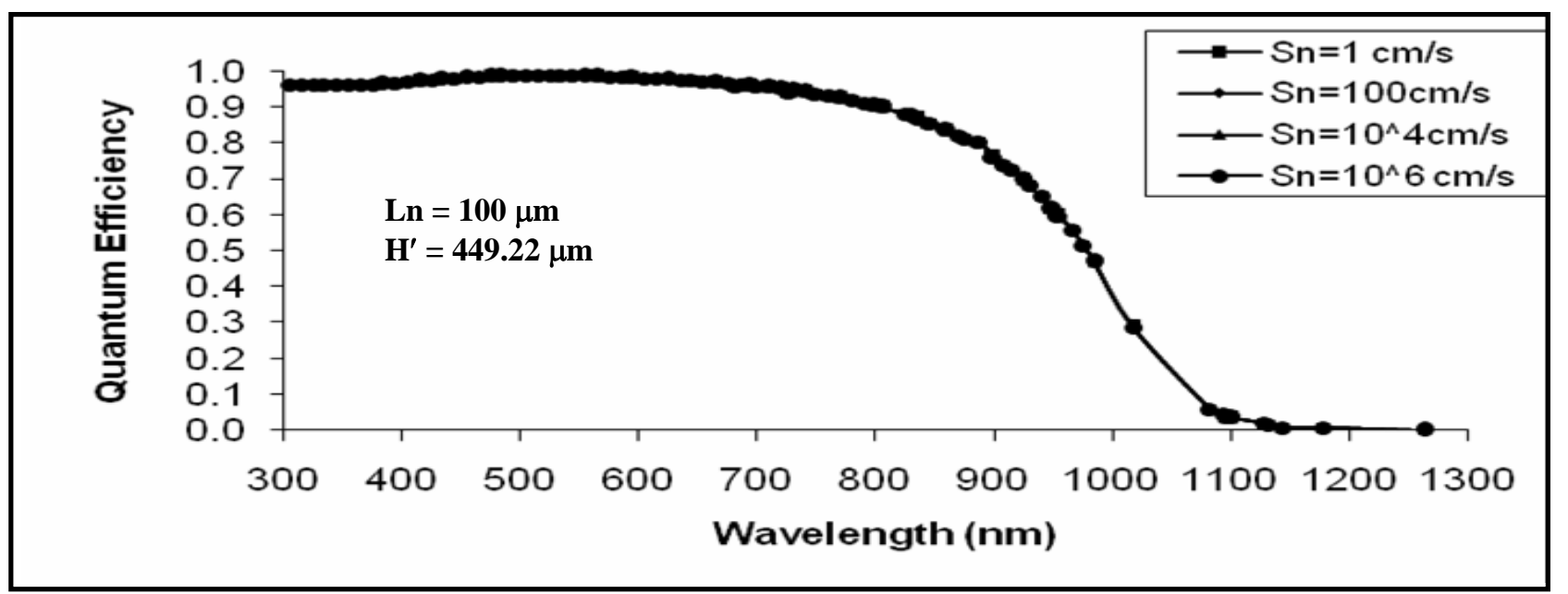

Fig. 4: $n+p$ solar cell internal quantum efficiency for different surface recombination velocities of electrons ( for short $\mathrm{Ln}$ ). 
Figure (5) shows when the hole diffusion length is greater than the emitter thickness, the front surface recombination velocity $(\mathrm{Sp})$ can affect on the quantum efficiency, because, the photocurrent is determined for radiation with light of different wavelengths. Since the short wavelength light is absorbed in the emitter, the current that is created in this region can show very clearly the influence of Sp. While when the hole diffusion length is shorter than $x j$, Sp does not affect on the quantum efficiency of solar cell as shown in Figure (6).

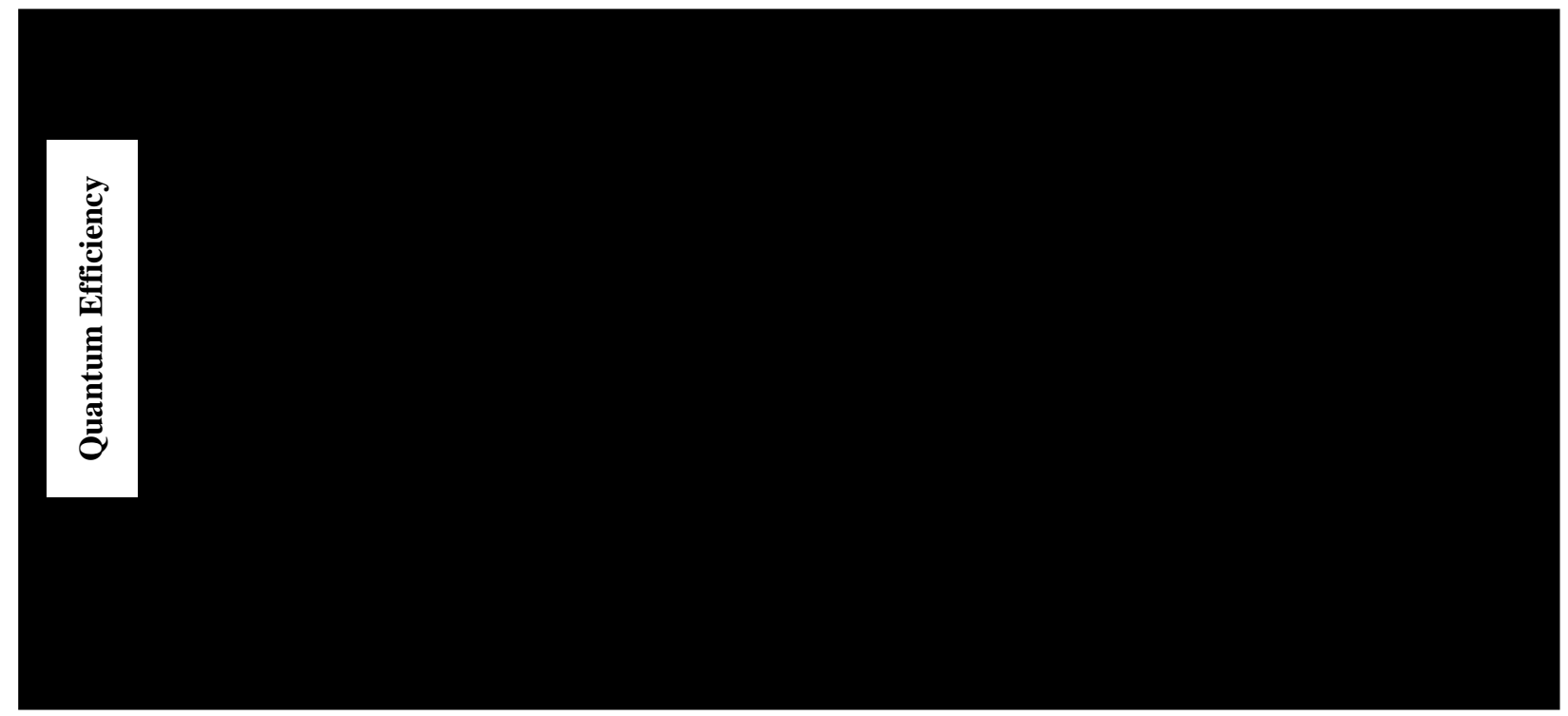

Fig. 5: $\mathrm{n}+\mathrm{p}$ solar cell internal quantum efficiency for different surface recombination velocities of holes ( for long $\mathrm{Lp}$ ).

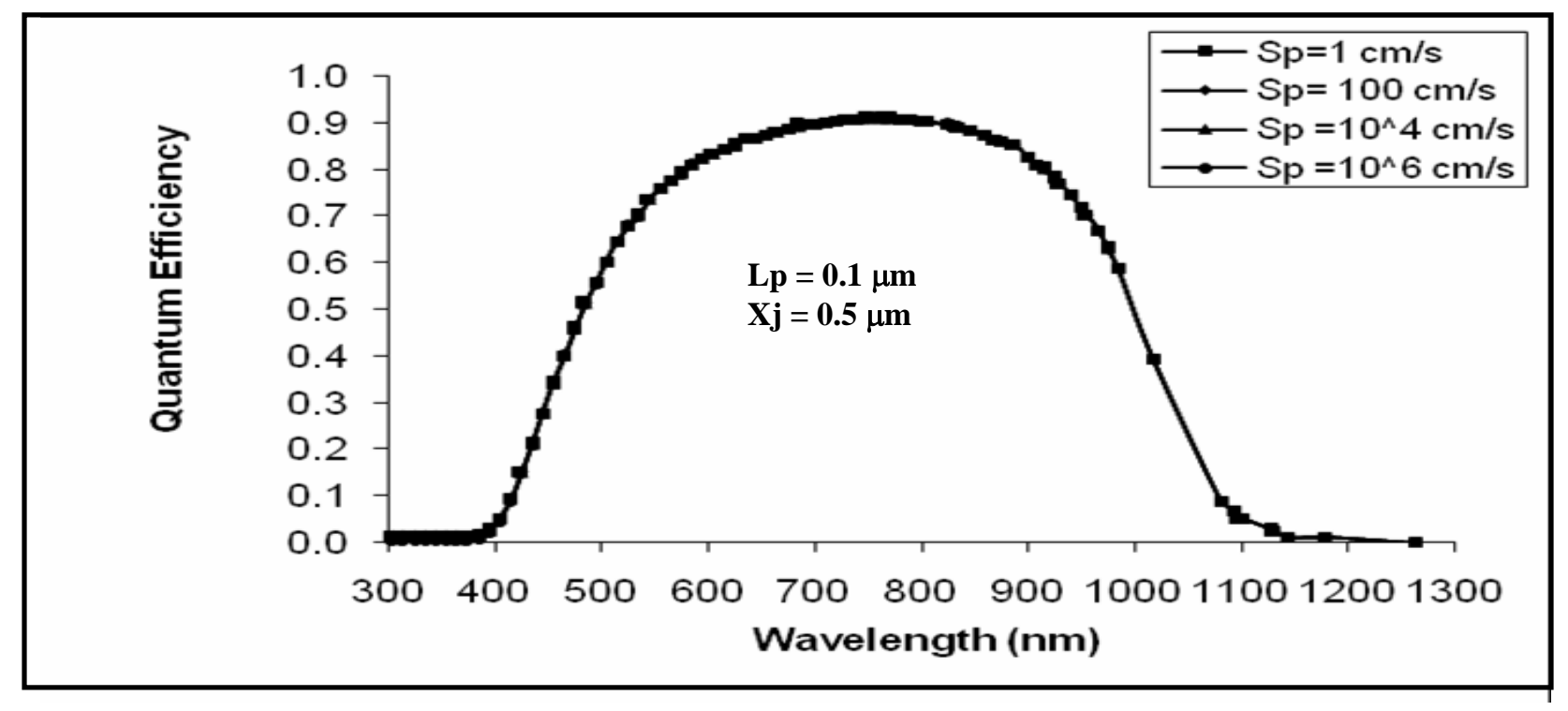

Fig. $6: n+p$ solar cell internal quantum efficiency for different surface recombination velocities of holes ( for short Lp).

The diffusion length of minority carriers in the bulk depends on the quality of the device in addition to the doping level, Figure (7) shows how this parameter makes the total 
Q. E. to change. As it is seen from the figure, the higher diffusion length of minority carriers in the bulk, the better quality of the device material, will provide higher quantum efficiency.

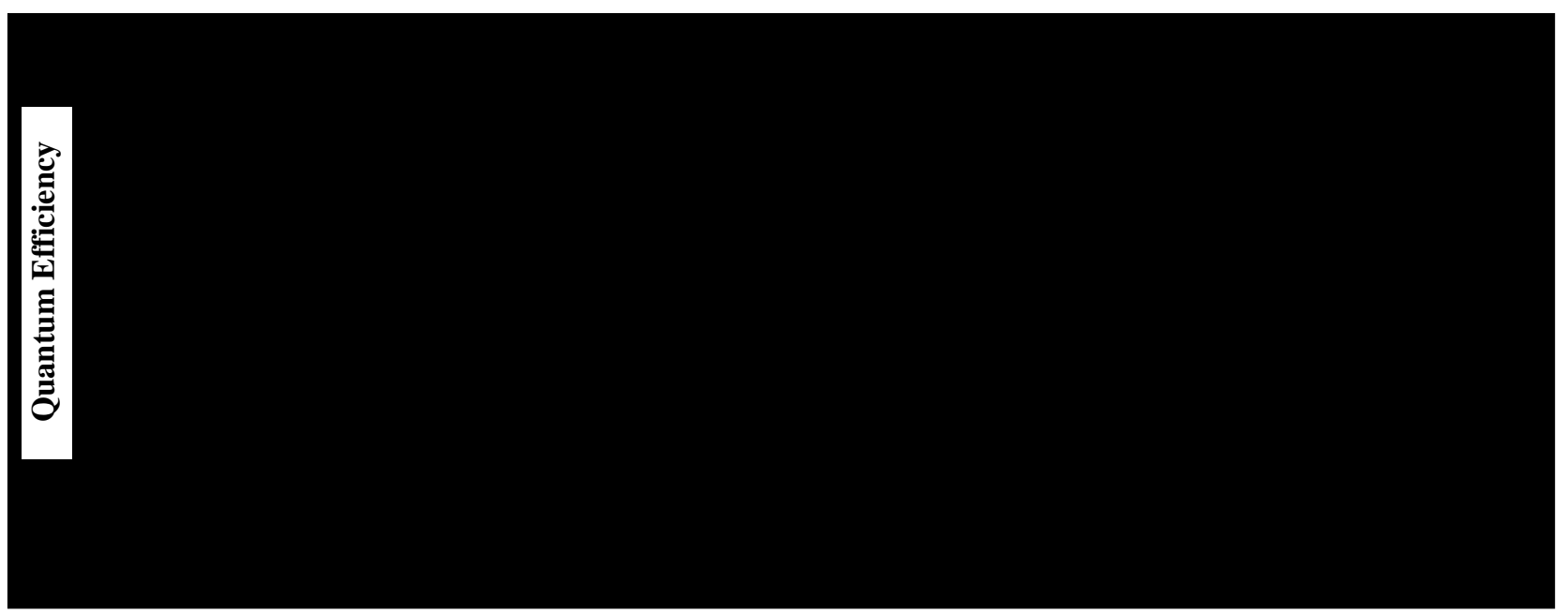

Fig. $7: n+p$ solar cell internal quantum efficiency for different diffusion lengths of electrons Ln.

Figure (8) shows when the diffusion length of the minority carriers (holes) is several times greater than the thickness of the emitter, the probability of recombination of holes will be very little, and the holes enables to travel to junction area and becomes as photocurrents and consequently, the total quantum efficiency becomes higher.

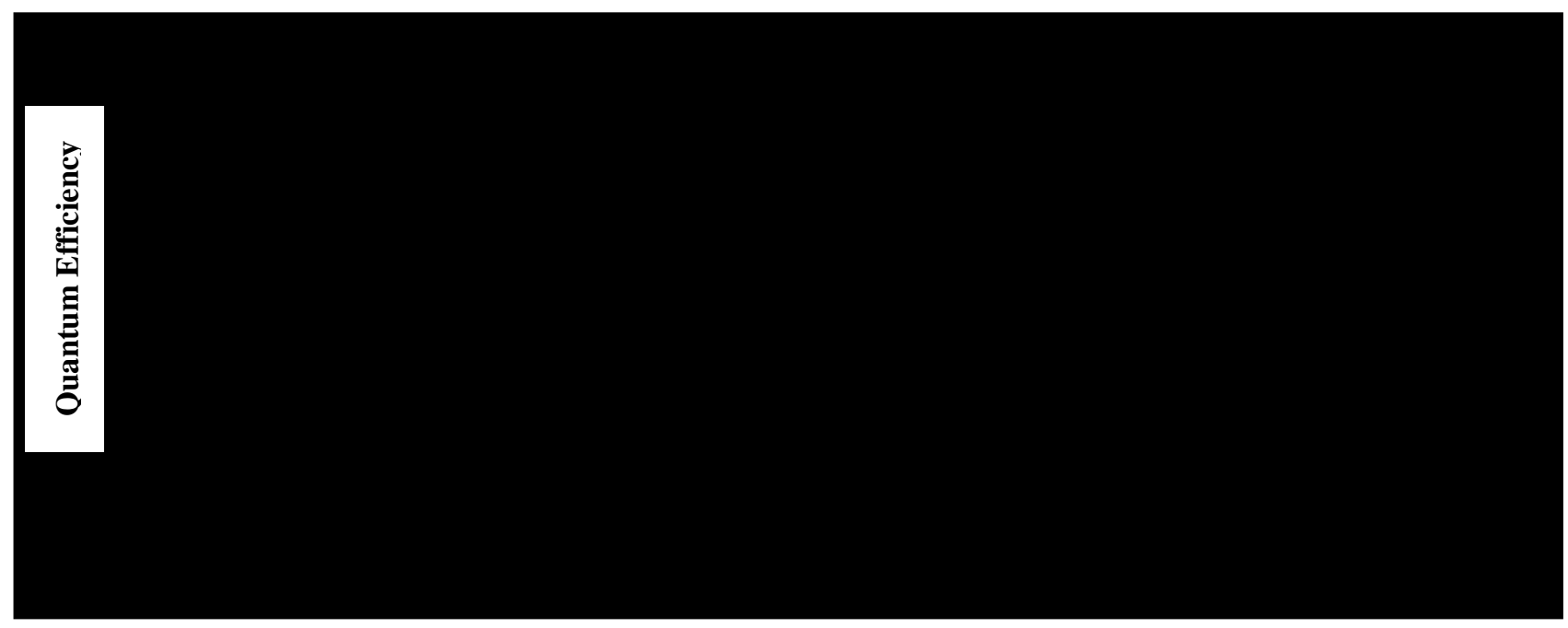

Fig. 8: $\mathrm{n}+\mathrm{p}$ solar cell internal quantum efficiency for different diffusion Lengths of holes Lp. 


\section{CONCLUSIONS}

1- When the diffusion length Ln of the charge carrier is comparable or more than the crystal thickness, then the quantum efficiency become high, and for very high quantum efficiency the surface recombination velocity (Sn) must be less than $100 \mathrm{~cm} / \mathrm{sec}$.

2- If the diffusion length Ln falls below the value of the crystal thickness, than the quantum efficiency will be almost independent of the surface recombination velocity $\mathrm{Sn}$.

3- In the short wavelength region the quantum efficiency reduces by increasing the surface recombination velocity $(\mathrm{Sp})$ especially when $\mathrm{Sp}>10^{4} \mathrm{~cm} / \mathrm{sec}$, but the quantum efficiency does not reduce when $\mathrm{Sp}<10^{4} \mathrm{~cm} / \mathrm{sec}$.

4- When the diffusion length $\mathrm{Lp}$ of the charge carrier is more than the penetration depth of the p-n junction, then the quantum efficiency become high.

\section{REFERENCES}

Castaner, L.; Silvestre, S. (2002). "Modeling Photovoltaic Systems using PSpice". John Wiley and Sons Ltd, England, pp. 20-39.

Goetzberger, A.; Knobloch, J.; Voss, B. (1998). "Crystalline Silicon Solar Cells". John Wiley and Sons Ltd.

Gray, J. L. (2003). "Handbook of Photovoltaic Science and Engineering". John Wiley and Sons Ltd, England, pp. 61-110.

Hovel, H. J. (1975). "Solar Cells, in Semiconductors and Semimetals". Vol. 11, Academic Press, pp. 15-29.

Jahanshah, F.; Sopian, K.; Zaidi, S.; Othman, M.; Amin, N.; Asim, N. (2009). Modeling the effect of p-n junction depth on the output of planer and rectangular textured solar cells. American J. Appl. Sci. 6 (4), 667-671.

Khalvati, F. (2003). Modeling and analysis of amorphous si /crystalline si heterojunction photovoltaic cells, University of Waterloo, Waterloo, Ontario, Canada, pp. 3-14.

Lipinski, M.; Panek, P. (2003). Optimization of monocrystalline silicon solar cell. OptoElectronics Review, 11(4), 291-295.

McIntosh, K.; Lau, G.; Cotsell, J.; Hanton, K.; Bätzner, D.; Bettiol, F.; Richards B. (2009). Increase in external quantum efficiency of encapsulated silicon solar cells from a luminescent down - shifting layer. Prog. Photovoltaic. Res. Appl., 17, 191-197.

Salih, S. I. (2000). Effect of additional vertical junction on the performance of the unconventional solar cells. J. Rafid. Sci. 11(4), 103-110. (In Arabic)

Sze, S. M.; Ng, K. K. (2007). "Physics of Semiconductor Devices", 3rd. edn., John Wiley and Sons Ltd. pp. 725-731.

Van Sark, W.; Meijerink, A.; Schropp, R.; Van Roosmalen, J.; Lysen, E. (2004). Modeling improvement of spectral response of solar cells by deployment of spectral converters containing semiconductor nanocrystals. Semiconductors, 38(8), 962969. 